\title{
Lifetime overweight and adult asthma: 1978/1979 Ribeirão Preto Birth Cohort, São Paulo, Brazil
}

\author{
Sobrepeso ao longo da vida e asma na idade \\ adulta: Coorte de Nascimento de 1978/1979, \\ Ribeirão Preto, São Paulo, Brasil
}
Sobrepeso a lo largo de la vida y asma en adultos: Cohorte de Nacimientos de 1978/1979 en Ribeirão Preto, São Paulo, Brasil

\author{
Luana Lopes Padilha 1 \\ Cecilia Claudia Costa Ribeiro 1 \\ Joelma Ximenes Prado Teixeira Nascimento 1 \\ Vanda Maria Ferreira Simões 1 \\ Fernanda Pino Vitti 2 \\ Viviane Cunha Cardoso 2 \\ Elcio Oliveira Vianna 2 \\ Marco Antônio Barbieri 2 \\ Antônio Augusto Moura da Silva 1 \\ Heloisa Bettiol 2
}

doi: 10.1590/0102-311X00041519

\begin{abstract}
Studies focusing on obesity and asthma frequently consider the weight at a given time; thus, modeling pathways through lifetime overweight may contribute to elucidate temporal aspects in this relationship. This study modeled the pathways in the association of lifetime overweight with asthma in adult life, using data from the 1978/1979 Birth Cohort, Ribeirão Preto, São Paulo, Brazil $(n=2,063)$ at birth (baseline), school age (9/11 years) and adult age (23/25 years). A theoretical model was proposed to explore the effects of lifetime overweight on asthma in adult life analyzed by structural equation modeling. Parental obesity (SC - standardized coefficent total $=0.211, p<0.001$; $\left.S C_{\text {direct }}=0.115, p=0.007\right)$ and overweight at school age $\left(S C_{\text {total }}=0.565, p<\right.$ $\left.0.0001 ; S C_{\text {direct }}=0.565, p<0.0001\right)$ were associated with overweight in adult life. Parental obesity $\left(S C_{\text {direct }}=0.105, p=0.047\right)$ and nutritional status at birth $\left(S C_{\text {total }}=-0.124, p=0.009 ; S C_{\text {direct }}=-0.131, p=0.007\right)$ were associated with asthma in adult life. A higher "current adult socieconomic situation" was inversely associated to overweight $\left(S C_{\text {direct }}=-0.171, p=0.020\right)$ and to asthma in adult life $\left(S C_{\text {total }}=-0.179, p=0.041 ; S C_{\text {direct }}=-0.182, p=0.039\right)$. Parental obesity showed a transgenerational effect in weight, triggering to childhood and adulthood overweight. Parallel to underweight at birth, parental obesity was also a risk to asthma in adult life. While, the socioeconomic status in adult life protected from both, overweight and asthma.
\end{abstract}

Overweight; Life Cycle Stages; Structural Equation Modeling; Asthma
Correspondence

C. C. C. Ribeiro

Universidade Federal do Maranhão.

Rua Barão de Itapary 155, São Luís, MA 65020-070, Brasil. cecilia_ribeiro@hotmail.com

1 Universidade Federal do Maranhão, São Luís, Brasil. 2 Faculdade de Medicina de Ribeirão Preto, Universidade de São Paulo, Ribeirão Preto, Brasil. 


\section{Introduction}

Asthma is a chronic disease that affects 235 million people all over the world 1 ; and that is being consistently associated with other non-communicable chronic diseases (NCCD) 2 with which it appears to share physiopathological mechanisms that need to be better explored 3,4 .

Obesity is an important risk factor for NCCD, which is being associated with asthma from birth to adulthood 5,6,7,8,9. Overweight during childhood increases the risk to develop asthma during this phase of life $5,6,7,10,11$ or in the future 8,12 . Overweight and obesity have also been associated with asthma in adults, with a dose-response effect on body mass index (BMI) 9 .

Studies focusing on obesity and asthma frequently consider overweight at a given time 13,14,15,16. Few prospective studies on the association between obesity and asthma have adjusted the model for birth variables using regression models 17,18 .

The association between obesity and asthma involves a complex and temporal relationship between maternal prenatal weight, birth weight, childhood and even adulthood weight 19,20. Structural equation modeling (SEM) is a useful tool for the study of epidemiological multicausality phenomena 21.

Modeling the structure between lifetime overweight and asthma may contribute to a better understanding of the temporal aspects and direct and indirect pathways present in this relationship. Thus, this study modeled the pathways in the association of lifetime overweight and asthma in adults in the 1978/1979 Ribeirão Preto Birth Cohort, São Paulo, Brazil, using SEM.

\section{Method}

\section{Study design}

This was a prospective cohort study entitled From Perinatal Health to Young Adult Health: a Study of the 1978/1979 Birth Cohort conducted in the Hospitals of Ribeirão Preto, São Paulo.

Ribeirão Preto is a city located $320 \mathrm{~km}$ northeast from the state capital of São Paulo, in the Southeast region of Brazil, a wealthy industrialized region with a municipal human development index (M-HDI) of 0.626 in 1991 and 0.733 in 2000, occupying the sixth place in the ranking of the 645 municipalities in the State of São Paulo and 22nd place in the national ranking of the 5,561 municipalities of the country 22,23 .

\section{Participants and sample}

The baseline information (first follow-up) for the 1978/1979 Ribeirão Preto cohort was obtained with 9,067 interviews held with mothers immediately after delivery, corresponding to $98 \%$ of the live newborns delivered at the eight maternities from Ribeirão Preto, from June 1, 1978 to May 31, 1979. The proportion of mothers who were discharged from the hospital before they could be interviewed was $2.5 \%$, and less than $1 \%$ refused the interview. The newborns whose mothers did not reside in Ribeirão Preto $(\mathrm{N}=2,094)$ on the date of delivery were excluded 24 .

Thus, 6,973 newborns remained in the study, 6,827 of them being singletons and 146 being twins 24 . A total of 257 of the 6,827 singletons died during the first year of life 25 and 86 died by 20 years of age. Thus, 6,484 were left at 20 years of age 26 .

During the second follow-up of this cohort in 1987/1989, 2,861 children (43.5\% of the original cohort) were evaluated at 9-11 years of age, in private, state and municipal public schools 24 .

The third follow-up occurred in 1996/1997 and involved only males assessed at the time of recruitment for compulsory military service $(\mathrm{n}=2,048) 24$.

In the fourth follow-up, 2002-2004, one third of the cohort was sought, and 5,665 individuals among who were alive at 20 years of age were located. In this phase, 2,063 provided data for the questionnaires and for laboratory tests (Figure 1), corresponding to $31.8 \%$ of the original cohort 24 .

Data for the participants were used for analysis of lifetime overweight and its association with adult asthma in the three follow-up periods of the cohort: baseline, 2nd follow-up (school age, 9-11 


\section{Figure 1}

Flow diagram of the 1978/1979 Ribeirão Preto Birth Cohort, São Paulo, Brazil, 1978-2002/2004.

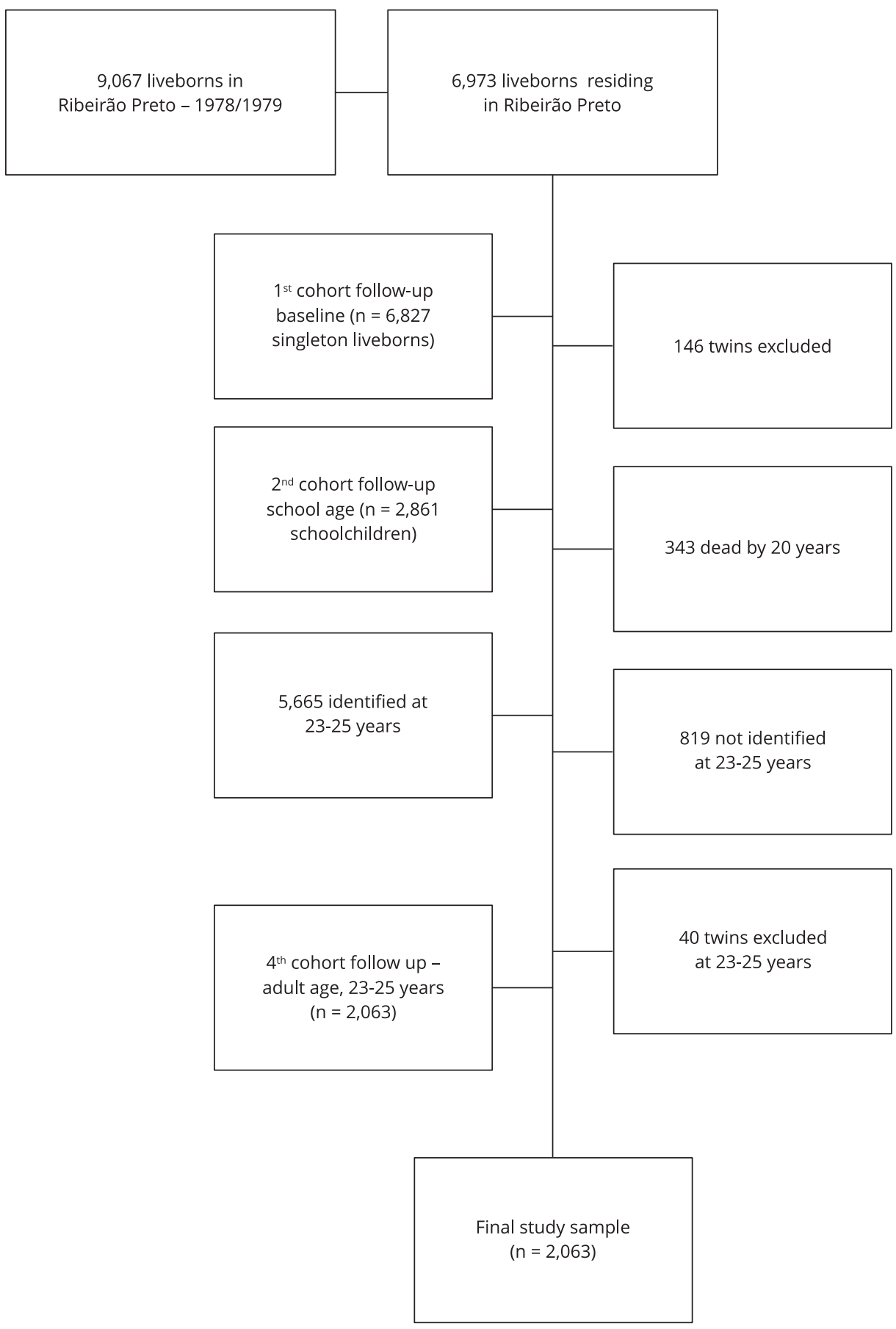


years) and $4^{\text {th }}$ follow-up (adult age, 23-25 years). The 3 rd follow-up was not used in the present study since it included only 18 -year-old males.

Thus, a total participants at the 4th follow-up of the cohort were included. This sample size permitted us to estimate, for the main outcomes of interest, prevalence values within the 50\% range with $1.8 \%$ relative precision, and prevalence values of about $10 \%$ with $1.1 \%$ relative precision, with a 95\% confidence interval (95\%CI). Methodological details regarding this cohort are available in previous studies 24,27 .

\section{Data collection}

Data collection for the cohort included interviews, the application of structured questionnaires, anthropometric exams, examination of medical records, and the bronchial hyperresponsiveness test.

At birth (baseline), the following information was used: maternal schooling (years of study), maternal occupation, family income (in minimum wages), newborn sex (male and female), and birth weight (grams) and length $(\mathrm{cm})$.

Birth weight and length were measured by trained personnel using appropriate instruments. The newborns were weighed without clothes on a baby weighing scale with $10 \mathrm{~g}$ precision calibrated weekly. Length at birth was measured with the newborn lying in the supine position on a neonatometer 28 and the data were checked in order to obtain the newborns' weight per length score (z-score).

At school age, information was obtained about the students' current weight $(\mathrm{kg})$ and height (meters) measured according to the recommended techniques 29 and obtained by duly trained personnel in order to determine the growth scores (z-score) of the BMI for age. At the time of weight measurement, students wore a school uniform and were instructed to remove shoes, socks, and to empty their pockets 29 . To measure the weight, the scales used in the schools were used when they were in use; the weight measurement was performed to the nearest $100 \mathrm{~g}$. When the school did not have a scale or it was defective, a scale was used by the Department of Child Care and Pediatrics, Faculty of Medicine of Ribeirão Preto, University of São Paulo specially assigned for this purpose 30 .

To measure the students' height, we used anthropometers manufactured exclusively for the research, whose measurements were taken in centimeters, to the nearest $0.5 \mathrm{~cm} 30$. The students were instructed to remove all props from their hair, shoes, and socks, and were placed in an upright, anatomical position, arms freely loosened along the trunk, looking straight into the horizon 29.

At adult age, the following information was obtained: adult's age (years), schooling (years of study), occupation, family income (minimum wages), current weight $(\mathrm{kg})$, height (meters) and report of maternal and paternal obesity - history of parental obesity, by the participant.

Adult weight and height were measured by trained personnel according to standard techniques, with the subject barefoot and wearing light clothing 31 . Anthropometric measurements were obtained with a periodically calibrated Filizola precision scale and with an anthropometer standing against the wall for measurements in the orthostatic position 32.

Information about medical diagnosis of asthma, wheezing during the last 12 months, sensation of tightness in the chest and shortness of breath during the last 12 months was obtained by applying the Respiratory Health Survey 27 questionnaire containing questions on these symptoms and diagnosis.

Bronchial hyperresponsiveness was also measured by the methacholine bronchoprovocation test. The test was applied using methacholine chloride (Sigma, St. Louis, USA) diluted in phosphate buffered saline according to international criteria 33. The procedure was carried out by a trained and experienced technician, a physiotherapist and a doctor at the laboratory of Pneumology Service of the University Hospital, Faculty of Medicine of Ribeirão Preto, University of São Paulo 27.

\section{Data processing and statistical analysis}

Due to the occurrence of losses on follow-up, the baseline and school phase variables were compared between the adults that attended or did not attend the 4 th cohort follow-up, using chi-square test. It was observed that participants born to unskilled manual working mothers $(\mathrm{p}=0.001)$ with 0 to 4 years of schooling $(\mathrm{p}<0.0001)$, whose families had a monthly income of 0 to 1.9 minimum wages $(\mathrm{p}<0.0001)$ attended less the $4^{\text {th }}$ follow-up period of the study. On this basis, the sample was weighted 
by calculating the probability of participants attending the $4^{\text {th }}$ cohort follow-up as a function of the birth variables significantly associated in the chi-square test using a logistic regression model. The inverse of this probability of selection was then calculated and this variable was used to weigh the SEM estimates using the Stata software, version 14.0 (https://www.stata.com).

\section{Latent variable}

Latent variables result from the combination of various observed variables (indicator variable). The use of latent variables permits a better statistical estimate by representing the theoretical concepts in a more appropriate manner. Furthermore, in a latent variable only common variance shared by different indicators persists, resulting in the estimated effects free from the bias originated by measurement errors 34 .

The indicators for the all latent variables were selected based on the convergent loadings $(>0.50)$ that formed this construct in exploratory factorial analyses (EFA). Model fit was assessed based on the following fit indices: (a) p-value $<0.05$ in the chi-square test $\left(\chi^{2}\right)$; (b) $p>0.05$ and upper $90 \%$ confidence interval limit $<0.08$ for the Root Mean Square Error of Approximation (RMSEA); (c) Comparative Fit Index (CFI) and Tucker-Lewis Index (TLI) values > 0.95; and (d) Weighted Least Square Mean and Variance Adjusted (WLSMV) value $<134$.

Then, confirmatory factorial analysis (CFA) was carried out in order to verify the factors previously determined by EFA 34, adopting the same criteria used in the EFA, with the inclusion of discriminant validity, i.e., the correlations between the indicators should not be excessively high ( $>0.90$ ), since each indicator should measure a distinct aspect of the latent variable 34 . The modindices (modification index) command was used to obtain suggestions of changes in the proposed latent variable 21. Exploratory and confirmatory factorial analyses were carried out using the Mplus software, version 7.0 (https://www.statmodel.com/).

\section{- Latent variable: prenatal (baseline) socioeconomic situation}

The latent variable "prenatal socioeconomic situation" (prenatal SES) consisted of the following variables: (a) maternal schooling ( $1=0$ to 4 years; $2=5$ to 8 years; $3=9$ to 11 years, and $4=12$ or more years of study); (b) maternal occupation ( 1 = unskilled manual worker; $2=$ semi-skilled and skilled manual worker; 3 = non-manual worker, according to the International Standard Classification of Occupation (ISCO) 35; (c) monthly family income based on the Brazilian national minimum wage in force during the $1978 / 1979$ period, categorized as: $1=0$ to 1.9 minimum wages; $2=2$ to 2.9 minimum wages; 3 = 3 to 4.9 minimum wages; $4=5$ or more minimum wages.

\section{- Latent variable: current socioeconomic situation of the adult (4th cohort follow-up)}

The latent variable socioeconomic situation of the adult (current adult SES) consisted of the following variables: (a) adult's schooling ( $1=0$ to 4 years; $2=5$ to 8 years; $3=9$ to 11 years and $4=12$ or more years of study); (b) adult's occupation ( 1 = unskilled manual worker; 2 = semi-skilled manual worker; 3 = skilled manual worker; and 4 = non-manual worker) 35 ; (c) monthly family income based on the Brazilian national minimum wage in force during the 2002/2004 period, categorized as: $1=$ less than 1 minimum wage; $2=1$ to 2.9 minimum wages; $3=3$ to 4.9 minimum wages; $4=5$ to 9.9 minimum wages; and $5=10$ or more minimum wages.

\section{Observed variables indicating lifetime obesity}

The following observed variables represent lifetime overweight: (a) 1st follow-up (baseline): weight per length $\mathrm{z}$-score (categorized as: 0 = underweight, $\mathrm{z}$-score $<-2 ; 1=$ normal weight, $\mathrm{z}$-score $\geq-2$ and $\leq$ +1 , and 2 = overweight, $z$-score > +1) 36; (b) 2nd follow-up (school age): BMI for schoolchild at age 9-11 years (categorized as: $0=$ malnutrition, $\mathrm{z}$-score $<-2 ; 1=$ normal weight, $\mathrm{z}$-score $\geq-2$ and $\leq+1$, and 2 $=$ overweight, $\mathrm{z}$-score $>+1$ ) 36; (c) $4^{\text {th }}$ follow-up (adult age): adult's BMI (categorized as: 0 = malnutrition, $<18.5 \mathrm{~kg} / \mathrm{m}^{2} ; 1$ = normal weight, $18.5-24.99 \mathrm{~kg} / \mathrm{m}^{2}$; and $2=$ overweight, $\left.\geq 25 \mathrm{~kg} / \mathrm{m}^{2}\right) 37$ and report 
of history of parental obesity by the participant (categorized as $0=$ no report of parental obesity; $1=$ yes, report of maternal or paternal obesity; or 2 = yes, report of both maternal and paternal obesity).

\section{Outcome: asthma}

Asthma was a continuous latent variable deduced from the correlation between five indicators in EFA: (a) self-report of a medical diagnosis of asthma $(1=$ yes or $0=n o)$; (b) presence of wheezing in the last 12 months $(1=$ yes or $0=$ no); (c) measurement of bronchial hyperresponsiveness (categorized as: $1=\leq 4 \mathrm{mg} / \mathrm{mL}$ to indicate bronchial hyperresponsiveness or obstructive pattern with compatible spirometry or $0=>4 \mathrm{mg} / \mathrm{mL}$, absence of bronchial hyperresponsiveness); (d) sensation of chest tightening sometimes when waking up during the last 12 months $(1=$ yes or $0=$ no); (e) shortness of breath during the day at rest over the last 12 months $(1=$ yes or $0=$ no); shortness of breath during the night over the last 12 months $(1=$ yes or $0=$ no). From these indicators, those with convergent loads in EFA (above 0.50) were selected. This latent variable was evaluated in CFA, adopted according to the measures analyzed previously.

\section{Proposed theoretical model}

In the proposed theoretical model, the "prenatal SES" would be a more distal determinant (exogenous latent variable), exerting its effects on the development of asthma outcome and on all the remaining dependent variables of the model. Parental obesity, as a proxy indicator of the interaction of genotypic-phenotypic components in the history of obesity in the family environment, potentially affects the other variables related to overweight (at birth, schoolchild and adult life). In a temporal sequence, lifetime overweight variables (parental obesity, overweight at birth and schoolchild and adult overweight) may be associated with asthma in adult life. Finally, as a more proximal determinant, "current adult SES" would be associated with an increased risk of overweight and asthma during adulthood (Figure 2).

\section{Structural equation modeling (SEM)}

SEM is an epidemiological tool used to test hypotheses on relationships between latent variables (nonobserved variables) and observed variables, permitting the analysis of a set of structural equations 38 .

The WLSMV estimator, theta parameterization for the control of residual variances 38 , was used in SEM, in addition to weighting the estimates by loss of follow-up. To determine whether the model showed good fit, the same estimates previously described for CFA were considered 21,34. The chisquare, degrees of freedom and p-value were evaluated but were not adopted as parameters for model fitting due to their sensitivity to sample size.

The command for the verification of modification indices (modindices) was used to test if suggestions could improve model fit. Modindices values higher than 10 were used to generate a new model 21, as long as these pathways were plausible from a theoretical viewpoint.

The effect of observed variables and latent variables on the outcomes were analyzed as standardized coefficients (SC), being considered significant when p-value $<0.05$. The total, direct and indirect effects were estimated 38 .

\section{Results}

The characteristics of the adults from the cohort and of their parents are listed in Tables 1 and 2. Among the adults, the prevalence of bronchial hyperresponsiveness was $20.7 \%(\mathrm{n}=427)$, the prevalence of medical diagnosis of asthma was $15.2 \%(n=313)$ and the prevalence of wheezing over the last 12 months was $19.4 \%(\mathrm{n}=401)$ (Table 2$)$.

The initial latent variable "Asthma" in EFA showed convergent loads higher than 0.50 for the following indicators: medical diagnosis of asthma (standardized coefficient - SC $=0.745$ ), wheezing $(\mathrm{SC}=0.553)$ and measurement of bronchial hyperresponsiveness $(\mathrm{SC}=0.702)$, with these three 
Structural equation model exploring the effects of socioeconomic situation and lifetime overweight on adult asthma. 1978/1979 Ribeirão Preto Birth Cohort, São Paulo, Brazil, 1978-2002/2004.

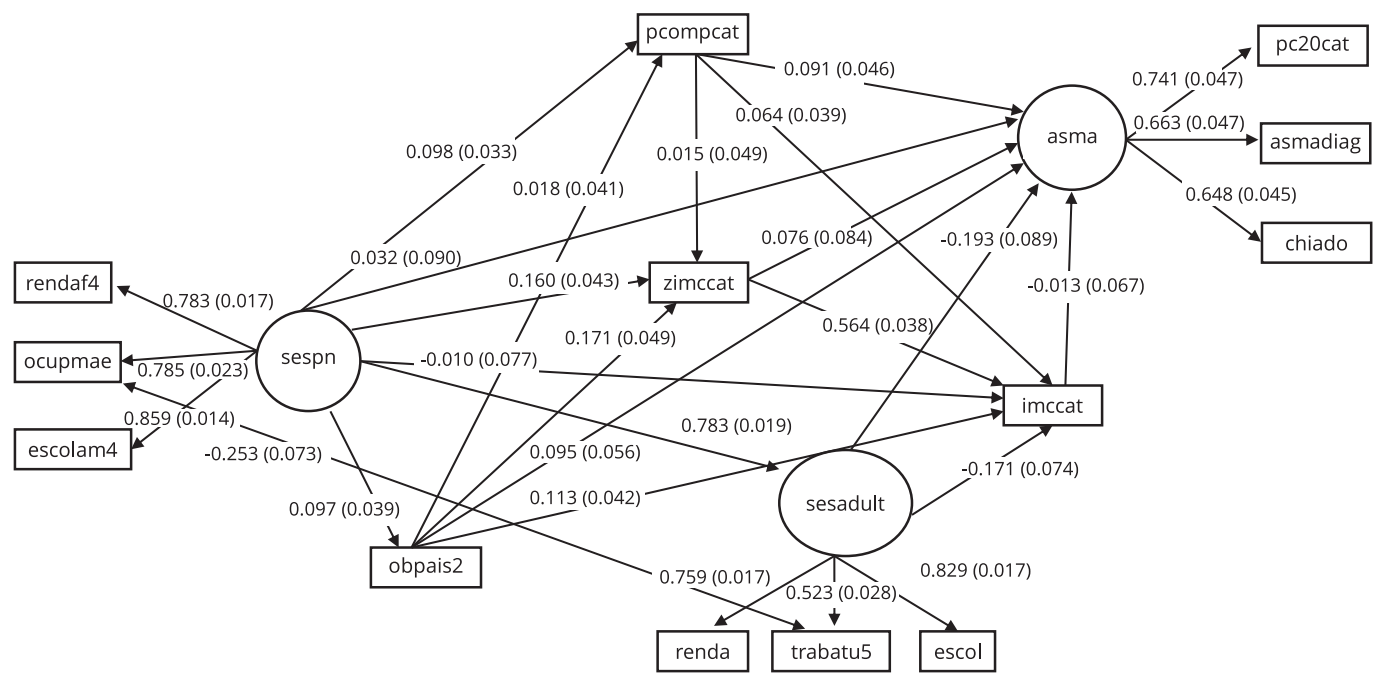

asma: latent variable of asthma; asmadiag: diagnosis of asthma of the 4th cohort follow-up. chiado: presence of wheezing in the last 12 months of the $4^{\text {th }}$ cohort follow-up; escol: years of study for the adult schooling of the 4 th cohort follow-up; escolam4: maternal schooling at birth; imccat: adult BMI of the 4th cohort follow-up; obpais2: history of parental obesity; ocupmae: maternal occupation at birth; pc20cat: measurement of bronchial hyperresponsiveness in $\mathrm{mg} / \mathrm{dL}$ of the 4 th cohort follow-up; pcompcat: weight per length z-score at birth; renda: monthly family income of the 4th cohort follow-up; rendaf4: family income at birth; sesadult: latent variable of the socioeconomic situation of the adult of the 4 th cohort follow-up; sespn: latent variable of the socioeconomic situation of the family at birth; trabatu5: adult occupation of the 4th cohort follow-up; zimccat: BMI for schoolchild age of 9-11 years.

indicators being used in the formation of the latent variable "Asthma" in the SEM analysis (data not shown in tables).

In the SEM model, each indicator of the latent variables "prenatal SES” and "current adult SES" had factorial loadings above 0.60 and all the indicators of these latent variables had significant p-values $(\mathrm{p}<0.0001)$ (Table 3; Figure 2).

Higher "prenatal SES” values were associated with parental obesity $\left(\mathrm{SC}_{\text {direct }}=0.101, \mathrm{p}=0.009\right)$ and with overweight at birth $\left(\mathrm{SC}_{\text {total }}=0.131, \mathrm{p}<0.0001\right.$, and $\left.\mathrm{SC}_{\text {direct }}=0.126, \mathrm{p}<0.0001\right)($ Table 4).

Higher "prenatal SES” values $\left(\mathrm{SC}_{\text {total }}=0.183, \mathrm{p}<0.0001\right.$, and $\left.\mathrm{SC}_{\text {direct }}=0.155, \mathrm{p}<0.0001\right)$ and parental obesity $\left(\mathrm{SC}_{\text {total }}=0.170, \mathrm{P}=0.001\right.$, and $\left.\mathrm{SC}_{\text {direct }}=0.166, \mathrm{p}=0.001\right)$ were associated with overweight at school age. "Prenatal SES" also had a positive indirect effect on overweight at school age, with this effect being mediated by parental obesity $\left(\mathrm{SC}_{\text {indirect }}=0.017, \mathrm{p}=0.039\right)$ (Table 4$)$.

Parental obesity $\left(\mathrm{SC}_{\text {total }}=0.211, \mathrm{p}<0.0001\right.$, and $\left.\mathrm{SC}_{\text {direct }}=0.115, \mathrm{p}=0.007\right)$ and overweight at school age $\left(\mathrm{SC}_{\text {total }}=0.565, \mathrm{p}<0.0001\right.$, and $\left.\mathrm{SC}_{\text {direct }}=0.565, \mathrm{p}<0.0001\right)$ were associated with adult overweight, whereas lower "current adult SES" values protected against adult overweight $\left(\mathrm{SC}_{\text {direct }}=\right.$ -0.171, $\mathrm{p}=0.016$ ). Parental obesity also had a positive indirect effect on adult overweight, with this effect being mediated by overweight at school age $\left(\mathrm{SC}_{\text {indirect }}=0.094, \mathrm{p}=0.001\right)$ (Table 4).

An association was also observed between "prenatal SES" and "current adult SES" $\left(\mathrm{SC}_{\text {direct }}=0.779\right.$, $\mathrm{p}<0.0001$ ) (data not shown in the tables).

Among the lifetime overweight indicators studied here, parental obesity was associated with asthma continuous variables during adult life $\left(\mathrm{SC}_{\text {total }}=0.105, \mathrm{p}=0.047\right)$. And, at the other extreme, 
Table 1

Sociodemographic, economic and nutritional characteristics during the prenatal period and at school age. Ribeirão Preto, São Paulo, Brazil, 1978-2002/2004

\begin{tabular}{|c|c|c|}
\hline Variable & $\mathbf{n}$ & $\%$ \\
\hline \multicolumn{3}{|l|}{ 1st cohort follow-up - baseline } \\
\hline \multicolumn{3}{|l|}{ Maternal schooling (years of study) } \\
\hline $0-4$ & 920 & 44.6 \\
\hline $5-8$ & 557 & 27.0 \\
\hline $9-11$ & 331 & 16.0 \\
\hline 12 or more & 215 & 10.4 \\
\hline No information * & 40 & 1.9 \\
\hline \multicolumn{3}{|l|}{ Maternal occupation } \\
\hline Unskilled manual worker & 1,748 & 84.7 \\
\hline Semi-skilled and skilled manual worker & 231 & 11.2 \\
\hline Non-manual worker & 46 & 2.2 \\
\hline No information * & 38 & 1.8 \\
\hline \multicolumn{3}{|l|}{ Family income at birth (minimum wages) ** } \\
\hline $0.0-1.9$ & 309 & 15.0 \\
\hline $2.0-2.9$ & 329 & 15.9 \\
\hline $3.0-4.9$ & 443 & 21.5 \\
\hline 5.0 or more & 611 & 29.6 \\
\hline No information * & 371 & 18.0 \\
\hline \multicolumn{3}{|l|}{ Nutritional status at birth } \\
\hline Underweight & 72 & 3.5 \\
\hline Normal weight & 1,473 & 71.4 \\
\hline Overweight & 367 & 17.8 \\
\hline No information * & 151 & 7.3 \\
\hline \multicolumn{3}{|l|}{ 2nd cohort follow-up - school age } \\
\hline \multicolumn{3}{|l|}{ Nutritional status of the schoolchildren } \\
\hline Malnutrition & 51 & 2.5 \\
\hline Normal weight & 892 & 43.2 \\
\hline Overweight & 204 & 9.9 \\
\hline No information * & 916 & 44.4 \\
\hline Total & 2,063 & 100.00 \\
\hline
\end{tabular}

* Values ignored or not provided;

** Values of the national minimum wage effective in 1978/1979. 


\section{Table 2}

Sociodemographic, economic, nutritional and respiratory characteristics of adults. Ribeirão Preto, São Paulo, Brazil, 19782002/2004

\begin{tabular}{|c|c|c|}
\hline Variable & $\mathbf{n}$ & $\%$ \\
\hline \multicolumn{3}{|l|}{ Adults' sex } \\
\hline Male & 995 & 48.2 \\
\hline Female & 1,068 & 51.8 \\
\hline \multicolumn{3}{|l|}{ Adults' schooling (years of study) } \\
\hline $0-4$ & 58 & 2.8 \\
\hline $5-8$ & 262 & 12.7 \\
\hline $9-11$ & 1,039 & 50.4 \\
\hline 12 or more & 704 & 34.1 \\
\hline \multicolumn{3}{|l|}{ Current occupation of the adults } \\
\hline Uskilled and semi-skilled manual worker & 424 & 20.6 \\
\hline Skilled manual worker & 342 & 16.6 \\
\hline Non-manual worker & 434 & 21.0 \\
\hline No information * & 863 & 41.8 \\
\hline \multicolumn{3}{|l|}{ Family income of the adults (minimum wages) ** } \\
\hline$<1.0$ & 220 & 10.7 \\
\hline $1.0-2.9$ & 461 & 22.3 \\
\hline $3.0-4.9$ & 631 & 30.6 \\
\hline $5.0-9.9$ & 404 & 19.6 \\
\hline$\geq 10.0$ & 196 & 9.5 \\
\hline No information * & 151 & 7.3 \\
\hline \multicolumn{3}{|l|}{ History of parental obesity } \\
\hline No & 1,349 & 65.4 \\
\hline Yes, mother or father & 288 & 14.0 \\
\hline Yes, mother and father & 58 & 2.8 \\
\hline No information * & 368 & 17.8 \\
\hline \multicolumn{3}{|l|}{ Nutritional status of the adults } \\
\hline Malnutrition & 118 & 5.7 \\
\hline Normal weight & 1,201 & 58.2 \\
\hline Overweight & 741 & 35.9 \\
\hline No information * & 3 & 0.2 \\
\hline \multicolumn{3}{|l|}{ Bronchial hyperresponsiveness measurements } \\
\hline$>4 \mathrm{mg} / \mathrm{mL}$ (without bronchial hyperresponsiveness) & 1,495 & 72.5 \\
\hline$\leq 4 \mathrm{mg} / \mathrm{mL}$ (with bronchial hyperresponsiveness) & 427 & 20.7 \\
\hline No information* & 141 & 6.8 \\
\hline \multicolumn{3}{|l|}{ Medical diagnosis of asthma } \\
\hline Yes & 313 & 15.2 \\
\hline No & 1,739 & 84.3 \\
\hline No information * & 11 & 0.5 \\
\hline \multicolumn{3}{|l|}{ Wheezing } \\
\hline Yes & 401 & 19.4 \\
\hline No & 1,660 & 80.5 \\
\hline No information * & 2 & 0.1 \\
\hline Total & 2,063 & 100.00 \\
\hline
\end{tabular}

* Values ignored or not provided;

** Values of the national minimum wage effective in 2002/2004. 
Table 3

Factorial loadings, standard error and p-value for the final latent variables of prenatal socioeconomic situation, current socioeconomic situation of adults and asthma in adults, by structural equation modeling (SEM). Ribeirão Preto, São Paulo, Brazil, 1978-2002/2004.

\begin{tabular}{|c|c|c|c|}
\hline Latent variable & Factorial loadings & Standard error & p-value \\
\hline \multicolumn{4}{|l|}{ Prenatal SES * } \\
\hline Family income & 0.783 & 0.017 & $<0.0001$ \\
\hline Maternal schooling & 0.857 & 0.015 & $<0.0001$ \\
\hline Maternal occupation & 0.786 & 0.023 & $<0.0001$ \\
\hline \multicolumn{4}{|l|}{ Current adult SES ** } \\
\hline Family income & 0.752 & 0.017 & $<0.0001$ \\
\hline Adult's schooling & 0.842 & 0.016 & $<0.0001$ \\
\hline Current adult's occupation & 0.601 & 0.022 & $<0.0001$ \\
\hline \multicolumn{4}{|l|}{ Asthma } \\
\hline Bronchial hyperresponsiveness measurement & 0.732 & 0.046 & $<0.0001$ \\
\hline Medical diagnosis of asthma & 0.671 & 0.047 & $<0.0001$ \\
\hline Wheezing & 0.649 & 0.045 & $<0.0001$ \\
\hline
\end{tabular}

SES: socioeconomic situation.

* Prenatal SES: Iatent variable of the socioeconomic situation of the family;

** Current adult SES: latent variable of the current socioeconomic situation of the adults.

underweight at birth was positively associated with adult's asthma continuous variables $\left(\mathrm{SC}_{\text {total }}=\right.$ $-0.124, \mathrm{p}=0.009$ e $\left.\mathrm{SC}_{\text {direct }}=-0.131 ; \mathrm{p}=0.007\right)($ Table 5).

Higher "prenatal SES values" $\left(\mathrm{SC}_{\text {total }}=-0.105, \mathrm{P}=0.009\right)$ and higher "current adult $\mathrm{SES}$ " $\left(\mathrm{SC}_{\text {total }}=\right.$ $-0.179, \mathrm{p}=0.041$ e $\left.\mathrm{SC}_{\text {direct }}=-0.182, \mathrm{p}=0.039\right)$ had a protective effect in adult's asthma continuous variables (Table 5).

\section{Discussion}

In the present study, parental obesity and overweight at school age were associated with overweight in adults, whereas a higher "current adult SES" protected them against this outcome. Parental obesity and underweight at birth were variables related to asthma. While the larger "SES of prenatal" and larger "SES of the adult" were protective of asthma in adult life.

Parental obesity was associated with adult obesity, having a direct effect as well as an indirect effect via overweight at school age. These findings are consistent with the literature, which shows that a higher maternal 39,40 or paternal 41,42 BMI is associated with a higher childhood BMI. Maternal obesity has already been associated with obesity of the child during adult life 43,44. Meta-analysis findings have also revealed an association between a high childhood BMI and adult obesity 45. Parental obesity appears as a marker for the complex interaction between genetic, epigenetic and environmental factors, thus illustrating the joint contribution of them and/or family shared trajectories 42 .

Higher "prenatal SES" values were a risk factor for parental obesity, for birth overweight and for overweight at school age, while higher "current adult SES" values were a protective factor against adult overweight. These distinct effects of latent SES variables on overweight outcomes at different time points in cohort follow-ups reflect the nutritional transition that has been occurring over the last decades 46 . In Brazil obesity was shifting towards groups with greater social vulnerability 47 .

The effect of parental obesity asthma in adult life may be explained by the development of synergic interactions between genes and environment, with the children of obese individuals being genetically predisposed to excess weight gain within obesogenic domestic environments 48 . Taken together, these factors may result in other inflammatory and/or chronic diseases, asthma being one of them 49 . 
Table 4

Effect of socioeconomic situation and of lifetime overweight outcomes on adult asthma. Ribeirão Preto, São Paulo, Brazil, $1978-2002 / 2004$.

\begin{tabular}{|c|c|c|c|c|c|}
\hline Explanatory variable & $\begin{array}{l}\text { Intermediate outcomes of } \\
\text { lifetime overweight }\end{array}$ & Effect & Factor loading & Standard error & p-value \\
\hline \multirow[t]{6}{*}{ Prenatal SES * } & Parental obesity & Direct & 0.101 & 0.039 & 0.009 \\
\hline & Nutritional status at birth & Total & 0.131 & 0.033 & $<0.0001$ \\
\hline & & Direct & 0.126 & 0.034 & \\
\hline & Nutritional status of the & Total & 0.183 & 0.042 & $<0.0001$ \\
\hline & schoolchildren & Direct & 0.155 & 0.044 & $<0.0001$ \\
\hline & & Indirect via parental obesity & 0.017 & 0.008 & 0.039 \\
\hline \multirow[t]{5}{*}{ Parental obesity } & Nutritional status of the & Total & 0.170 & 0.049 & 0.001 \\
\hline & schoolchildren & Direct & 0.166 & 0.057 & 0.001 \\
\hline & Nutritional status of the adult & Total & 0.211 & 0.039 & $<0.0001$ \\
\hline & & Direct & 0.115 & 0.042 & 0.007 \\
\hline & & $\begin{array}{l}\text { Indirect via nutritional } \\
\text { status of the schoolchildren }\end{array}$ & 0.094 & 0.029 & 0.001 \\
\hline Nutritional status of the & Nutritional status of the adult & Total & 0.565 & 0.038 & $<0.0001$ \\
\hline schoolchildren & & Direct & 0.565 & 0.038 & $<0.0001$ \\
\hline Current SES of the adult ** & Nutritional status of the adult & Direct & -0.171 & 0.071 & 0.016 \\
\hline
\end{tabular}

SES: socioeconomic situation.

* Latent variable of the prenatal socioeconomic situation;

** Latent variable of the socioeconomic situation of the adult.

Even if parental obesity was the only variable related to lifetime overweight with an effect on adult's continuous asthma variable, the association of parental obesity with the intermediate outcomes of schoolchild nutritional status and of adult nutritional status may help explain why previous studies have detected an association of these last variables with asthma 6,9,16,50.

At the other extreme regarding weight, underweight at birth was associated to asthma in adult life. Meta-analysis studies have shown an association of both low birthweight 50 and high birthweight8 with the future risk of asthma using weight for gestational age. The present study added knowledge to this theme, since it classified the nutritional status at birth according to an anthropometric indicator, permitting the verification of underweight and overweight, as well as the pathways triggered from them over time.

Intrauterine mechanisms that affect immunity or pulmonary development have been suggested as possible explanations for this effect of fetal underweight on asthma 51 . However, the epigenetic mechanism of the sparing phenotype, by which the intrauterine environment of nutritional restriction increases the chance of adult obesity 52,53 , may not be an explanation for our asthma findings since the effect of underweight at birth on asthma continuous variables was direct, without a pathway that would go through overweight.

The effect of "prenatal SES" and "current adult SES" on the risk of asthma corroborates findings from other studies which showed that the indicators related to a lower socioeconomic level are associated with a higher risk of asthma, using observed variables such as education, occupation, income, and material goods $54,55,56$. The present study contributes to this knowledge by showing that inequality situations represented by lower values of the latent variable SES, with a lower determination error and observed at two time points in life were associated with adult's asthma continuous variables.

These results showed that "current adult SES" exerted a proximal and direct protective effect on adult's asthma continuous variables, a fact that may be explained by the access to healthier dietary choices due to higher income and schooling 57,58 , to labor activity or to living in urban environments with lower risks for asthma 54 .

A limitation of this study was that the prenatal obesity variable was reported by the participants during the $4^{\text {th }}$ cohort follow-up, without a precise indication of the beginning of this condition. How- 
Effect of socioeconomic situation and of lifetime overweight outcomes on adult asthma continuous variable. Ribeirão Preto, São Paulo, Brazil, 1978-2002/2004.

\begin{tabular}{|c|c|c|c|}
\hline Variables explaining adult asthma/Effect & Factor loading & Standard error & p-value \\
\hline \multicolumn{4}{|l|}{ Prenatal SES * } \\
\hline Total & -0.105 & 0.040 & 0.009 \\
\hline Direct & 0.027 & 0.091 & 0.764 \\
\hline Indirect via current adult SES ** & -0.142 & 0.069 & 0.040 \\
\hline \multicolumn{4}{|l|}{ Current adult SES ** } \\
\hline Total & -0.179 & 0.088 & 0.041 \\
\hline Direct & -0.182 & 0.089 & 0.039 \\
\hline \multicolumn{4}{|l|}{ Parental obesity } \\
\hline Total & 0.105 & 0.053 & 0.047 \\
\hline Direct & 0.100 & 0.056 & 0.072 \\
\hline \multicolumn{4}{|l|}{ Nutritional status at birth } \\
\hline Total & -0.124 & 0.047 & 0.009 \\
\hline Direct & -0.131 & 0.049 & 0.007 \\
\hline \multicolumn{4}{|l|}{ Nutritional status of the schoolchildren } \\
\hline Total & 0.080 & 0.058 & 0.170 \\
\hline Direct & 0.090 & 0.084 & 0.281 \\
\hline \multicolumn{4}{|l|}{ Nutritional status of the adult } \\
\hline Direct & -0.018 & 0.067 & 0.785 \\
\hline
\end{tabular}

Note: factorial loading of the effect evaluated.

* Latent variable of the prenatal socioeconomic situation;

** Latent variable of the socioeconomic situation of the adult.

ever, parental obesity was used as a proxy for the interaction of genotype-phenotype components in the history of the family environment 59 . In this respect, in thisstudy parental overweight was found to be the starting point for other indicators of lifetime overweight in the offspring.

It was not possible here to confirm the association between parental obesity and schoolchild overweight with childhood asthma ${ }^{6}$ since these data were not available for the cohort. However, more distal variables linked to weight such as parental obesity and underweight at birth were associated with adult asthma.

Strong points of this study were the pioneering approach to the exploration of this set of variables as indicators of overweight in a manner interrelated with asthma during adult life, the use of a birth cohort of Brazilian children involving a large sample analyzed at three distinct times, i.e., birth, school age and adulthood, and the use of weighting by the inverse of the probability of participating in the follow-ups, minimizing the possibility of selection biases due to sample losses and increasing the external validity of the study.

We also emphasize the SEM analysis with the formation of latent variables for "prenatal SES" and "current adult SES", permitting the formation of these variables of complex definition and reducing the measurement errors. In addition, SEM permitted to estimate the total, direct and indirect effects, for a better interpretation of the results obtained, signaling these effects in the temporal relationships between lifetime overweight and asthma in adulthood.

Another strong point of this study was the continuous variable "Asthma", which included the variable observed with the bronchial hyperresponsiveness test by methacholine bronchoprovocation associated with other symptoms of the disease 60 . Other symptoms of asthma were included in the latent variable reducing the error of determination in the diagnosis of the disease. So far, only one study has used a latent variable for the construction of this asthma variable and was conducted on a target public differing from the present study, i.e., in children 61 . 
Parental obesity was the starting point for the overweight pathways in childhood and adulthood, with an evident transgenerational effect. A greater weight at childhood continued to be a risk for overweight during adulthood. The effect of "prenatal SES" was a marked risk for parental obesity and for overweight at birth and during childhood. On the other hand, SES at the fourth follow-up of the cohort was a protective factor against adult overweight, characterizing the nutritional transition that has been occurring in Brazil over the last few decades.

Regarding weight pathways in asthma, parental obesity and underweight at birth were risk factors for asthma continuous variables during adulthood. SES at the two follow-up times of the cohort was a protective factor against adult asthma. Taken together, these data suggest that public policies should focus on appropriate weight within the family environment and at birth as a form of preventing lifetime obesity and asthma.

\section{Contributors}

L. L. Padilha performed the data analysis and wrote the article. C. C. C. Ribeiro formulated the research question, wrote and revised the article. J. X. P. T. Nascimento, V. M. F. Simões, F. P. Vitti and A. A. M. Silva and E. O. Vianna has critically reviewed the article. V. C. Cardoso, M. A. Barbieri and H. Bettiol participated in the research and review of the article. All authors approved the final version of the article for publication.

\section{Additional informations}

ORCID: Luana Lopes Padilha (0000-0002-71622726); Cecilia Claudia Costa Ribeiro (0000-00030041-7618); Joelma Ximenes Prado Teixeira Nascimento (0000-0002-2871-8685); Vanda Maria Ferreira Simões (0000-0001-8351-1348); Fernanda Pino Vitti (0000-0002-3309-183X); Viviane Cunha Cardoso (0000-0002-2677-5600); Elcio Oliveira Vianna (0000-0003-1902-6326); Marco Antônio Barbieri (0000-0001-8060-1428); Antônio Augusto Moura da Silva (0000-0003-4968-5138); Heloísa Bettiol (0000-0001-8744-4373).

\section{Acknowledgments}

The authors acknowledge the study participants, the research team for the collection of the information. They acknowledge the support of the Faculty of Medicine of Ribeirão Preto, University of São Paulo (FMRP-USP) for the conduction and execution of this study.

\section{References}

1. World Health Organization. Asthma. 2017. http://http://www.who.int/news-room/ fact-sheets/detail/asthma (accessed on 02/ Jul/2018).

2. Gershon AS, Guan J, Wang C, Victor JC, To T. Describing and quantifying asthma comorbidity [corrected]: a population study. PLoS One 2012; 7:e34967.

3. Cazzola M, Segreti A, Calzetta L, Rogliani P. Comorbidities of asthma: current knowledge and future research needs. Curr Opin Pulm Med 2013; 19:36-41.

4. Sutherland ER. Linking obesity and asthma. Ann N Y Acad Sci 2014; 13:31-41.

5. Mebrahtu TF, Feltbower RG, Greenwood DC, Parslow RC. Childhood body mass index and wheezing disorders: a systematic review and meta-analysis. Pediatr Allergy Immunol 2015; 26:62-72.

6. Liu PC, Kieckhefer GM, Gau BS. A systematic review of the association between obesity and asthma in children. J Adv Nurs 2013; 69:144665.

7. Papoutsakis C, Priftis KN, Drakouli M, Prifti S, Konstantaki E, Chondronikola M, et al. Childhood overweight/obesity and asthma: is there a link? A systematic review of recent epidemiologic evidence. J Acad Nutr Diet 2013; 113:77-105.

8. Flaherman V, Rutherford GW. A meta-analysis of the effect of high weight on asthma. Arch Dis Child 2006; 91:334-9.

9. Beuther DA, Sutherland ER. Overweight, obesity, and incident asthma: a meta-analysis of prospective epidemiologic studies. Am J Respir Crit Care Med 2007; 175:661-6. 
10. McCallister M, Medrano R, Wojcicki J. Early life obesity increases the risk for asthma in San Francisco born Latina girls. Allergy Asthma Proc 2018; 39:273-80.

11. Lang JE, Bunnell HT, Hossain MJ, Wysocki T, Lima JJ, Finkel TH, et al. Being overweight or obese and the development of asthma. Pediatrics 2018; 142:pii: e20182119.

12. Ulrik CS, Lophaven SN, Andersen ZJ, Sorensen TI, Baker JL. BMI at school age and incident asthma admissions in early adulthood: a prospective study of 310,211 children. Clin Epidemiol 2018; 10:605-12.

13. Cottrell L, Neal WA, Ice C, Perez MK, Piedimonte G. Metabolic abnormalities in children with asthma. Am J Respir Crit Care Med 2011; 183:441-8

14. Matos SM, Jesus SR, Saldiva SR, Prado MS, D'Innocenzo S, Assis AM, et al. Overweight, asthma symptoms, atopy and pulmonary function in children of 4-12 years of age: findings from the SCAALA cohort in Salvador, Bahia, Brazil. Public Health Nutr 2011; 14:1270-8.

15. Ma J, Xiao L, Knowles SB. Obesity, insulin resistance and the prevalence of atopy and asthma in US adults. Allergy 2010; 65:1455-63.

16. Cetlin AA, Gutierrez MR, Bettiol H, Barbieri MA, Vianna EO. Influence of asthma definition on the asthma-obesity relationship. BMC Public Health 2012; 12:844.

17. Jeong Y, Jung-Choi K, Lee JH, Lee HY, Park EA, Kim YJ, et al. Body weight at birth and at age three and respiratory illness in preschool children. J Prev Med Public Health 2010; 43:369-76

18. Zhang Z, Lai HJ, Roberg KA, Gangnon RE, Evans MD, Anderson EL, et al. Early childhood weight status in relation to asthma development in high-risk children. J Allergy Clin Immunol 2010; 126:1157-62.

19. Peters U, Dixon AE, Forno E. Obesity and asthma. J Allergy Clin Immunol 2018; 141:116979.

20. Lang JE. Obesity and childhood asthma. Curr Opin Pulm Med 2019; 25:34-43.

21. Byrne B. Structural equation modeling with Mplus: basic concepts, applications and programming. New York: Routledge; 2012.

22. Programa das Nações Unidas para o Desenvolvimento; Instituto de Pesquisa Econômica Aplicada; Fundação João Pinheiro. Índice de Desenvolvimento Humano Municipal 2000. http://www.atlasbrasil.org.br/2013/pt/ranking (accessed on 11/Jun/2018).

23. Fundação Sistema Estadual de Análise de Dados. Informações dos municípios paulistas. São Paulo: Fundação Sistema Estadual de Análise de Dados; 2005.

24. Cardoso VC, Simoes VM, Barbieri MA, Silva AA, Bettiol H, Alves MT, et al. Profile of three Brazilian birth cohort studies in Ribeirao Preto, SP and São Luis, MA. Braz J Med Biol Res 2007; 40:1165-76.
25. Almeida LEA, Barbieri MA, Gomes UA, Reis PM, Chiaratti TM, Vasconcelos V, et al. Birthweight, social class and infant mortality in Ribeirão Preto, São Paulo. Cad Saúde Pública 1992; 8:190-8.

26. Oliveira ZA, Bettiol H, Gutierrez MR, Silva AA, Barbieri MA. Factors associated with infant and adolescent mortality. Braz J Med Biol Res 2007; 40:1245-55.

27. Barbieri MA, Bettiol H, Silva AA, Cardoso VC, Simoes VM, Gutierrez MR, et al. Health in early adulthood: the contribution of the 1978/79 Ribeirão Preto birth cohort. Braz J Med Biol Res 2006; 39:1041-55.

28. Barbieri M, Gomes U, Barros Filho A, Bettiol $\mathrm{H}$, Almeida L, Silva AA. Perinatal health in Ribeirao Preto, Brazil: a question of method. Cad Saúde Pública 1989; 5:376-87.

29. Lohman T, Roche AF, Martorell R. Anthropometric standardization reference manual. Champaign: Human Kintetics; 1988.

30. Bettiol H, Sabbag Filho D, Haeffner LS, Barbieri MA, Silva AA, Portela A, et al. Do intrauterine growth restriction and overweight at primary school age increase the risk of elevated body mass index in young adults? Braz J Med Biol Res 2007; 40:1237-43.

31. Cameron N. The measurement of human growth. New York: Sheridan House; 1984.

32. Rezende F, Rosado L, Franceschinni S, Rosado G, Ribeiro R, Marins JC. Revisão crítica dos métodos disponíveis para avaliar a composição corporal em grandes estudos populacionais e clínicos. Arch Latinoam Nutr 2007; 57:327-34.

33. Crapo RO, Casaburi R, Coates AL, Enright PL, Hankinson JL, Irvin CG, et al. Guidelines for methacholine and exercise challenge testing-1999. This official statement of the American Thoracic Society was adopted by the ATS Board of Directors, July 1999. Am J Respir Crit Care Med 2000; 161:309-29.

34. Kline RB. Principles and practice of structural equation modeling. New York: Guilford Press; 2011.

35. Olsen J, Frische G. Social differences in reproductive health. A study on birth weight, stillbirths and congenital malformations in Denmark. Scand J Soc Med 1993; 21:90-7.

36. Multicentre Growth Reference Study Group. WHO Child Growth Standards based on length/height, weight and age. Acta Paediatr Suppl 2006; 450:76-85.

37. World Health Organization. Physical status: the use and interpretation of anthropometry. Geneva: World Health Organization; 1995.

38. Muthén LK, Muthén BO. Mplus: statistical analysis with latent variables. User's guide. Los Angeles: Muthén \& Muthén; 2010.

39. Botton J, Heude B, Maccario J, Borys JM, Lommez A, Ducimetiere P, et al. Parental body size and early weight and height growth velocities in their offspring. Early Hum Dev 2010; 86:445-50. 
40. Knight B, Shields BM, Hill A, Powell RJ, Wright D, Hattersley AT. The impact of maternal glycemia and obesity on early postnatal growth in a nondiabetic Caucasian population. Diabetes Care 2007; 30:777-83.

41. Regnault N, Botton J, Forhan A, Hankard R, Thiebaugeorges O, Hillier TA, et al. Determinants of early ponderal and statural growth in full-term infants in the EDEN mother-child cohort study. Am J Clin Nutr 2010; 92:594602.

42. Linabery AM, Nahhas RW, Johnson W, Choh AC, Towne B, Odegaard AO, et al. Stronger influence of maternal than paternal obesity on infant and early childhood body mass index: the Fels Longitudinal Study. Pediatr Obes 2013; 8:159-69.

43. Rooney K, Ozanne SE. Maternal over-nutrition and offspring obesity predisposition: targets for preventative interventions. Int J Obes (Lond) 2011; 35:883-90.

44. Drake AJ, Reynolds RM. Impact of maternal obesity on offspring obesity and cardiometabolic disease risk. Reproduction 2010; 140:387-98.

45. Simmonds M, Burch J, Llewellyn A, Griffiths C, Yang H, Owen C, et al. The use of measures of obesity in childhood for predicting obesity and the development of obesity-related diseases in adulthood: a systematic review and meta-analysis. Health Technol Assess 2015; 19:1-336.

46. Popkin BM, Adair LS, Ng SW. Global nutrition transition and the pandemic of obesity in developing countries. Nutr Rev 2012; 70:3-21.

47. Goncalves H, Barros FC, Buffarini R, Horta BL, Menezes AMB, Barros AJD, et al. Infant nutrition and growth: trends and inequalities in four population-based birth cohorts in Pelotas, Brazil, 1982-2015. Int J Epidemiol 2019; 48 Suppl 1:i80-i8.

48. Fuentes Pacheco A, Carrillo Balam G, Archibald D, Grant E, Skafida V. Exploring the relationship between local food environments and obesity in UK, Ireland, Australia and New Zealand: a systematic review protocol. BMJ Open 2018; 8:e018701.

49. Bagby SP, Martin D, Chung ST, Rajapakse N. From the outside in: biological mechanisms linking social and environmental exposures to chronic disease and to health disparities. Am J Public Health 2019; 109(S1):S56-S63.
50. Xu XF, Li YJ, Sheng YJ, Liu JL, Tang LF, Chen ZM. Effect of low birth weight on childhood asthma: a meta-analysis. BMC Pediatr 2014; $14: 275$.

51. Forno E, Young OM, Kumar R, Simhan H, Celedon JC. Maternal obesity in pregnancy, gestational weight gain, and risk of childhood asthma. Pediatrics 2014; 134:e535-46.

52. Lillycrop KA. Effect of maternal diet on the epigenome: implications for human metabolic disease. Proc Nutr Soc 2011; 70:64-72.

53. Godfrey KM, Barker DJ. Fetal programming and adult health. Public Health Nutr 2001; 4:611-24.

54. Caldeira RD, Bettiol H, Barbieri MA, TerraFilho J, Garcia CA, Vianna EO. Prevalence and risk factors for work related asthma in young adults. Occup Environ Med 2006; 63:694-9.

55. Almqvist C, Pershagen G, Wickman M. Low socioeconomic status as a risk factor for asthma, rhinitis and sensitization at 4 years in a birth cohort. Clin Exp Allergy 2005; 35:612-8.

56. Corvalan C, Amigo H, Bustos P, Rona RJ. Socioeconomic risk factors for asthma in Chilean young adults. Am J Public Health 2005; 95:1375-81.

57. Uphoff E, Cabieses B, Pinart M, Valdes M, Anto JM, Wright J. A systematic review of socioeconomic position in relation to asthma and allergic diseases. Eur Respir J 2015; 46:364-74.

58. Hedlund U, Eriksson K, Ronmark E. Socioeconomic status is related to incidence of asthma and respiratory symptoms in adults. Eur Respir J 2006; 28:303-10.

59. Huang T, Hu FB. Gene-environment interactions and obesity: recent developments and future directions. BMC Med Genomics 2015; 8 Suppl 1:S2.

60. National Institute for Health and Care Excellence. Asthma: diagnosis and monitoring of asthma in adults, children and young people. London: National Institute for Health and Care Excellence; 2017.

61. Nascimento J, Ribeiro CCC, Batista RFL, de Britto Alves M, Simoes VMF, Padilha LL, et al. The first 1000 days of life factors associated with "childhood asthma symptoms": Brisa Cohort, Brazil. Sci Rep 2017; 7:16028. 


\section{Resumo}

Os estudos sobre obesidade e asma frequentemente analisam o peso em um determinado momento; portanto, a modelagem de trajetórias de sobrepeso ao longo da vida pode ajudar a explicar os aspectos temporais dessa relação. O estudo atual modelou as trajetórias na associação entre história de sobrepeso e asma na vida adulta, utilizando dados da Coorte de Nascimento de 1978/1979, Ribeirão Preto, São Paulo, Brasil ( $n=2.063)$, coletados ao nascer (linha de base), na idade escolar (9-11 anos) e na idade adulta (23-25 anos). Foi proposto um modelo teórico para explorar a associação entre o sobrepeso ao longo da vida e asma na vida adulta, analisada pela modelagem de equações estruturais. Obesidade dos pais (CP - coeficiente padronizado $_{\text {global }}=0,211, p<0,001 ; C P_{\text {direto }}=0,115$; $p=0,007)$ e sobrepeso na idade escolar $\left(C P_{\text {global }}\right.$ $\left.=0,565 ; p<0,0001 ; C P_{\text {direto }}=0,565 ; p<0,0001\right)$ mostraram associação com sobrepeso na idade adulta. Obesidade dos pais $\left(C P_{\text {direto }}=0,105\right.$; $p=0,047)$ e estado nutricional ao nascer $\left(C P_{\text {global }}=\right.$ - 0,124; $\left.p=0,009 ; C P_{\text {direto }}=-0,131 ; p=0,007\right)$ mostraram associação com asma na idade adulta. "Condição socioeconômica" mais alta na vida adulta mostrou associação inversa com sobrepeso $\left(C P_{\text {direto }}=-0,171, p=0,020\right)$ e com asma na vida adulta $\left(C P_{\text {global }}=-0,179 ; p=0,041 ; C P_{\text {direto }}=\right.$ $-0,182 ; p=0,039)$. Obesidade dos pais mostrou um efeito transgeracional sobre o peso, como gatiIho na infância e no sobrepeso na vida adulta. Em paralelo ao baixo peso ao nascer, a obesidade dos pais também esteve associada com asma na vida adulta. A condição socioeconômica na vida adulta mostrou efeito protetor contra sobrepeso e asma.

Sobrepeso; Estágios do Ciclo da Vida; Modelo de Equação Estrutural; Asma

\section{Resumen}

Los estudios que se centran en la obesidad y asma frecuentemente consideran el peso en un determinado momento; por este motivo, la creación de modelos de patrones de sobrepeso a lo largo de la vida quizás puede contribuir a elucidar aspectos temporales en esta relación. Este estudio modeló los patrones en la asociación de sobrepeso a lo largo de la vida con el asma en etapa adulta, usando datos de una cohorte nacimientos de 1978/1979, en Ribeirão Preto, São Paulo, Brasil ( $n=2.063)$, considerando: nacimiento (base de referencia), edad escolar (9-11 años) y edad adulta (23-25 años). Se propuso un modelo teórico para analizar los efectos del sobrepeso a lo largo de la vida en el asma, durante la etapa adulta, analizado mediante modelos de ecuaciones estructurales. La obesidad de los padres $\left(C E-\right.$ coeficiente estandarizado ${ }_{\text {total }}=$ 0,211, $\left.p<0,001 ; C E_{\text {directo }}=0,115 ; p=0,007\right) y$ sobrepeso en edad escolar $\left(C E_{\text {total }}=0,565 ; p<\right.$ 0,0001; $\left.C E_{\text {directo }}=0,565 ; p<0,0001\right)$ estuvieron asociados con sobrepeso en la vida adulta. La obesidad de los padres $\left(C E_{\text {directo }}=0,105 ; p=0,047\right) y$ el estatus nutricional al nacer $\left(C E_{\text {total }}=-0,124\right.$; $\left.p=0,009 ; C E_{\text {directo }}=-0,131 ; p=0,007\right)$ estuvieron asociados con el asma en la vida adulta. Un "condición socioeconómica actual en la etapa adulta" más alto estuvo inversamente asociado con el sobrepeso $\left(C E_{\text {directo }}=-0,171 ; p=0,020\right)$ y al asma en la vida adulta $\left(C E_{\text {total }}=-0,179 ; p=0,041\right.$; $\left.C E_{\text {direct }}=-0,182 ; p=0,039\right)$. La obesidad de los padres mostró un efecto transgeneracional en el peso, desencadenando sobrepeso en la infancia y etapa adulta. Junto al bajo peso al nacer, la obesidad de los padres fue también un riesgo para el asma en la etapa adulta. Mientras que el estatus socioeconómico en la etapa adulta protegía tanto ante el sobrepeso como el asma.

Sobrepeso; Estadios del Ciclo de Vida; Modelos de Ecuaciones Estructurales; Asma
Submitted on 15/Mar/2019

Final version resubmitted on 10/Jul/2019

Approved on 23/Aug/2019 